\title{
Fertilizer Program Impacts Yield and Blossom End Rot in Bell Pepper
}

\author{
Timothy Coolong ${ }^{1,4}$, Andre Luiz Biscaia Ribeiro da Silva ${ }^{2}$, and \\ Justin Shealey ${ }^{3}$
}

ADDITIONAL INDEX WORDs. calcium, Capsicum annumm, fertigation, liquid fertilizer, nitrogen, potassium

Summary. High-value vegetable crops such as bell pepper (Capsicum annuum) are heavily fertilized by growers who seek to maximize yields. Field experiments were conducted in Spring 2016 and 2017 evaluating two liquid fertilizers with and without calcium (Ca), applied at three nitrogen $(\mathrm{N})$ and potassium $(\mathrm{K})$ levels in two varieties of bell pepper to determine whether current fertilizer recommendations were adequate and whether fertilizer source impacted fruit yield and quality. Plants were grown using plastic mulch and drip irrigation following standard production practices for the region. Two liquid fertilizer programs $[7 \mathrm{~N}-0 \mathrm{P}-5.8(7-0-7)$ and $4 \mathrm{~N}-0 \mathrm{P}-6.6 \mathrm{~K} / 9 \mathrm{~N}-0 \mathrm{P}-0 \mathrm{~K}-11 \mathrm{Ca}(4-0-8 / \mathrm{CN} 9)]$ were applied twice weekly at three $\mathrm{N}$ rates $(175,200$, and $225 \mathrm{lb} /$ acre $\mathrm{N})$. Yield, cull rate, and foliar nutrient concentrations were measured. In 2016, total marketable yields were greatest [910 boxes/acre (28 lb/box)] and blossom end rot (BER) incidence (14.4\%) lowest in plants grown with the supplemental Ca (4-0-8/C9 fertilizer) at $175 \mathrm{lb} /$ acre $\mathrm{N}$. Cull rates increased in plants grown without supplemental Ca during the season (70-7 fertilizer), with BER incidence ranging from $22.9 \%$ to $27.2 \%$. Yields ranged from 590 to 740 boxes/acre in plants grown without supplemental Ca in 2016. In 2017, yields ranged from 530 to 790 boxes/acre in plants grown with supplemental $\mathrm{Ca}$ at 200 and $175 \mathrm{lb} /$ acre N, respectively. Culls due to BER were lower in 2017 than in 2016. In 2016, BER incidence was greater in 'PSO9979325' compared with 'Antebellum', despite no differences in total yield. Foliar nutrient levels were largely unaffected by fertilizer program; however, foliar $\mathrm{N}$ and $\mathrm{K}$ concentrations increased with the rate of $\mathrm{N}$ and $\mathrm{K}$ fertilization. The results of this study suggest that using liquid fertilizer program containing some Ca may benefit bell pepper growers in some, but not all, growing seasons.

G eorgia produced nearly 5300 acres of bell pepper valued at about $\$ 113$ million in 2016, (Wolfe and Stubbs, 2017) and is a leading bell pepper producing region in the United States. Nearly all of the bell pepper crop is grown on sandy soils in Southwest Georgia using plastic mulch and drip irrigation. These soils are well drained and subject to nutrient leaching (Delgado,

Received for publication 13 Dec. 2018. Accepted for publication 22 Jan. 2019.

Published online 28 February 2019.

Funding for this research was provided by the Georgia Vegetable Commodity Commission.

${ }^{1}$ Department of Horticulture, University of Georgia, 1111 Miller Plant Sciences, Athens, GA 30602

${ }^{2}$ Department of Horticulture, University of Georgia, 2360 Rainwater Road, Tifton, GA 31793

${ }^{3}$ Echols County Cooperative Extension Service, University of Georgia, 109 Courthouse Street, Statenville, GA 31648

${ }^{4}$ Corresponding author. E-mail: tcoolong@uga.edu.

This is an open access article distributed under the CC BY-NC-ND license (https://creativecommons.org/ licenses/by-nc-nd/4.0/).

https://doi.org/10.21273/HORTTECH04249-18
2002). As a result, $\mathrm{N}$ fertilizer recommendations for the Coastal Plain of Georgia call for the application of 150 to $200 \mathrm{lb} /$ acre of $\mathrm{N}$ for the production of bell peppers using plastic mulch and drip irrigation with rows spaced on 6-ft centers (Kissel and Sonon, 2008). Nitrogen fertilization recommendations have increased over time with changing production practices (Batal and Smittle, 1981). However, due to a lack of recent studies conducted on bell pepper fertilization in Georgia, current recommendations are largely based on interpretations of research conducted under similar growing conditions in other states. In Florida, $\mathrm{N}$ recommendations for bell pepper grown on predominately sandy soils using plastic mulch with drip irrigation are $200 \mathrm{lb} /$ acre (Hochmuth and Hanlon, 2010) for rows spaced on 6 - $\mathrm{ft}$ centers. Simonne et al. (2006) reported greatest yields when using $250 \mathrm{lb} /$ acre $\mathrm{N}$ with $133 \%$ of recommended irrigation on sandy soils in Florida. This indicates that nutrient requirements also are tied to irrigation regime for bell pepper. Maximum yields have been reported using 225 $\mathrm{lb} /$ acre $\mathrm{N}$ for drip irrigated bell peppers grown in clay loam soils in California (Hartz et al., 1993). In contrast, there was no significant difference in marketable yields for bell peppers grown in New Jersey on a sandy loam soil with $\mathrm{N}$ rates ranging between 135 and $300 \mathrm{lb} /$ acre $\mathrm{N}$ (Kline et al., 2011).

Although results of $\mathrm{N}$ fertilizer studies in bell pepper vary widely, research suggests that optimum yields for drip-irrigated bell pepper are obtained most often using $\approx 200 \mathrm{lb} /$ acre $\mathrm{N}$ in the Southeastern United States (Hochmuth and Hanlon, 2010). Zhang et al. (2010) reported a maximum economic return for bell pepper at $202 \mathrm{lb} /$ acre $\mathrm{N}$ in southern Ontario, Canada. In that study, optimal economic returns were realized with the $\mathrm{N}$ rate required to produce maximum yields. This was due to the relatively low cost of fertilizer required to produce each ton of bell pepper fruit. However, the authors did indicate that $\mathrm{N}$ use efficiency decreased significantly with increasing $\mathrm{N}$ application rates, which may lead to increased nutrient leaching. In some cases, excessive $\mathrm{N}$ application has been associated with increased vegetative growth and decreases in yield in bell pepper (Aliyu, 2000; Hochmuth and Hanlon, 2010).

\begin{tabular}{llll}
\hline $\begin{array}{l}\text { Units } \\
\text { To convert U.S. to SI, } \\
\text { multiply by }\end{array}$ & U.S. unit & SI unit & $\begin{array}{l}\text { To convert SI to U.S., } \\
\text { multiply by }\end{array}$ \\
\hline 0.4047 & $\mathrm{acre}(\mathrm{s})$ & $\mathrm{ha}$ & 2.4711 \\
0.3048 & $\mathrm{ft}$ & $\mathrm{m}$ & 3.2808 \\
3.7854 & $\mathrm{gal}$ & $\mathrm{L}$ & 0.2642 \\
2.54 & inch $(\mathrm{es})$ & $\mathrm{cm}$ & 0.3937 \\
0.4536 & $\mathrm{lb}$ & $\mathrm{kg}$ & 2.2046 \\
1.1209 & $\mathrm{lb} / \mathrm{acre}$ & $\mathrm{kg} \cdot \mathrm{ha}^{-1}$ & 0.8922 \\
0.0254 & $\mathrm{mil}(\mathrm{s})$ & $\mathrm{mm}$ & 39.3701 \\
1 & $\mathrm{ppm}$ & $\mathrm{mg} \cdot \mathrm{kg}^{-1}$ & 1 \\
1 & $\mathrm{ppm}$ & $\mathrm{mg} \cdot \mathrm{L}^{-1}$ & 1 \\
6.8948 & $\mathrm{psi}$ & $\mathrm{kPa}$ & 0.1450 \\
$\left({ }^{\circ} \mathrm{F}-32\right) \div 1.8$ & ${ }^{\circ} \mathrm{F}$ & ${ }^{\circ} \mathrm{C}$ & $\left({ }^{\circ} \mathrm{C} \times 1.8\right)+32$
\end{tabular}


In Georgia, the current $\mathrm{N}$ fertilizer recommendation for bell pepper grown using plastic mulch with drip irrigation suggests the application of $20 \%$ to $33 \%$ of the season total $\mathrm{N}$ before planting (Kissel and Sonon, 2008). Recommended application rates during the growing season range from 1 to $2 \mathrm{lb} /$ acre per day depending on the stage of crop development (Granberry et al., 2017). Frequent N fertilizer applications at low rates are recommended due to the low nutrient holding capacity of the soils in southern Georgia. Personal observations by the authors suggest that growers in southern Georgia fertilize bell peppers 2 to $5 \mathrm{~d}$ /week beginning $\approx 7$ to $10 \mathrm{~d}$ after transplanting. Although multiple daily fertigation events have been reported to increase yields and decrease the BER incidence in bell pepper (Silber et al., 2005), fertilizing more than once per day is logistically challenging for most growers in the region. Nearly all fertigation in the region is done using premixed liquid fertilizers containing $\mathrm{Ca}$ or $\mathrm{K}$ with nitrate as the $\mathrm{N}$ source. Growers generally avoid ammonium forms of $\mathrm{N}$ due to the association of ammonium with increased BER in bell pepper (Marti and Mills, 1991).

Factors affecting BER incidence in bell pepper are of significant concern to growers. In some seasons, losses due to BER can be more than $35 \%$ of the spring bell pepper crop for growers in Georgia (W.L. Brim, personal communication). In tomato (Solanum lycopersicum) and bell pepper fruit, BER is a symptom of a localized Ca deficiency occurring early in development (Bangerth, 1979; Marcelis and Ho, 1999). Genetics, growth rate, irrigation regime, relative humidity, and $\mathrm{Ca}$ fertilization have been reported to influence BER in pepper and tomato (DiazPerez and Hook, 2017; Tadesse et al., 2001; Taylor and Locascio, 2004; Taylor et al., 2004). In addition to the direct effects of Ca nutrition on BER, other nutrient cations, such as ammonium, sodium, and $\mathrm{K}$, have been shown to compete with $\mathrm{Ca}$ for uptake, increasing BER rates (Taylor and Locascio, 2004). Because leaves preferentially accumulate $\mathrm{Ca}$ compared with fruit, BER rates also may be increased in plants with excessive canopy growth (Taylor and Locascio, 2004).
Growers in Southern Georgia routinely alter fertilization programs for bell pepper based on season, variety grown, and weather conditions. Growers avoid ammonium-based fertilizers, follow regular irrigation schedules, and have general expectations of season total $\mathrm{N}$ levels to apply. Unfortunately, little research-based information is available on how commonly used liquid fertilizer sources and rates influence yield and quality. Furthermore, there are no published studies regarding the performance of bell pepper varieties incorporating resistance to all 11 races of bacterial leaf spot of pepper (Xanthomonas euvesicatoria) to different rates of fertilizer. Varieties incorporating this resistance now comprise more than $90 \%$ of planted bell pepper acreage in Georgia. Thus, the objectives of this study were to determine how two commonly used liquid fertilizer programs, with and without supplemental $\mathrm{Ca}$, affected yield and quality of two varieties of bell pepper at a range of $\mathrm{N}$ levels used by growers in southern Georgia.

\section{Materials and methods}

This study was conducted at The University of Georgia Tifton Vegetable Park in Tifton, GA (lat. $31^{\circ} 5^{\prime} \mathrm{N}$, long. $83^{\circ} 5^{\prime} \mathrm{W}$ ), in Spring 2016 and 2017. The soil is a Tifton loamy sand series $(0 \%$ to $2 \%$ slope $)$. Soil analyses were conducted before planting in both seasons. In 2016, the field used had a soil pH of 6.2 with 62,124 , and $867 \mathrm{lb} /$ acre of phosphorous $(\mathrm{P}), \mathrm{K}$, and $\mathrm{Ca}$, respectively. The field used in 2017 had a soil pH of 6.5 with 90,94 , and $1097 \mathrm{lb} /$ acre of $\mathrm{P}, \mathrm{K}$, and $\mathrm{Ca}$, respectively (Mehlich 3 extract; Waters Agricultural Laboratories, Camilla, GA). Soil test results in both years indicated a high, medium, and high supply of $\mathrm{P}, \mathrm{K}$, and $\mathrm{Ca}$, respectively. Seed of 'Antebellum' and 'PS09979325' (Seminis, St. Louis, MO) were sown into 200-cell trays (Speedling, Ruskin, FL) filled with soilless media (Pro-Mix BX; Premier Tech, Riviere-du-Loup, Quebec, Canada). Seedlings were greenhouse grown at temperature set points of $84 / 68{ }^{\circ} \mathrm{F}$ (day/night). Plants were watered twicedaily as needed and fertilized once daily after germination with a $150 \mathrm{mg} \cdot \mathrm{L}^{-1} \mathrm{~N}$ solution (20N-4.4P-16.6K; Scotts, Marysville, $\mathrm{OH}$ ).

Soils were fumigated with 194 $\mathrm{lb} /$ acre chloropicrin $+129 \mathrm{lb} / \mathrm{acre}$ 1,3-dichloropropene (Pic-Chlor 60; TriEst Ag Group, Tifton, GA) when plastic was laid. Irrigation was supplied with a single line of drip irrigation tubing [12-inch emitter spacing, $0.50 \mathrm{gal} / \mathrm{min}$ per $100 \mathrm{ft}$ at $10 \mathrm{psi}$ (Chapin DLX; Jain USA, Haines City, FL)]. Drip tape was placed in the center of the row at a depth of 1 to 2 inches. Fumigation, plastic laying, and pre-plant fertilizer were applied using a raised bed plastic mulch layer with attached fumigation system and fertilizer hopper (SuperBedder; Kennco Manufacturing, Ruskin, FL). Beds were 6 -inch-tall by 32 -inch-wide spaced on 6 -ft row centers covered with a 1.1-mil-thick totally impermeable film plastic mulch [TIF (Vaporsafe RM, 60-inch; Raven Industries, Sioux Falls, SD)]. A preplant homogenized $5.0 \mathrm{~N}-4.3 \mathrm{P}-12.5 \mathrm{~K}$ fertilizer (Rainbow Plant Food; Agrium, Tifton, GA) consisting of $25 \mathrm{lb} /$ acre $\mathrm{N}$ was placed in the row immediately before laying plastic mulch and incorporated when the raised bed was formed. No Ca was present in the preplant fertilizer. An herbicide mixture containing $0.12 \mathrm{lb} /$ acre flumioxazin (Chateau; Valent USA, Walnut Creek, CA), $0.7 \mathrm{lb} /$ acre S-metolachlor (Dual Magnum; Syngenta, Greensboro, NC), and $0.84 \mathrm{lb} /$ acre glyphosate (RoundUp WeatherMax; Monsanto, St. Louis, MO) was applied between rows with a shielded sprayer $\approx 2$ weeks before transplanting. Eight-week-old bell pepper seedlings were transplanted on 8 Apr. 2016 and 20 Mar. 2017 into a double-row configuration on each plastic bed. Between-row spacing was 18 inches and within-row spacing was 12 inches on each plastic bed. Each plot was $15 \mathrm{ft}$ long and contained 30 plants. About 10$\mathrm{ft}$ buffers were present between adjacent plots within a row of plastic mulch.

A factorial arrangement of treatments in a randomized complete block design with five replicates in 2016 and four replicates in 2017 was used. Treatments consisted of liquid fertilizer with and without supplemental $\mathrm{Ca}$, three fertilizer rates, and two bell pepper varieties ('Antebellum' and 'PS09979325'). Fertilizer programs consisted of plants receiving no supplemental $\mathrm{Ca}$ with two applications of 7-0-7 liquid fertilizer (7N-0P-5.8K; Big Bend Supply Co., Cairo, GA) weekly, or plants receiving additional weekly $\mathrm{Ca}$ with $\mathrm{N}$ applications split evenly between one 
application of 4-0-8 liquid fertilizer (4N-0P-6.4K; Big Bend Supply Co.) and a second application of CN9 liquid fertilizer $(9 \mathrm{~N}-0 \mathrm{P}-0 \mathrm{~K}-1 \mathrm{Ca})$. The $4-0-8$ fertilizer was derived primarily from salts of $\mathrm{K}$ nitrate, ammonium nitrate, and urea. The $7-0-7$ liquid fertilizer was derived primarily from salts of potassium nitrate and ammonium nitrate. The CN9 was derived primarily from $\mathrm{Ca}$ nitrate, with ammonium nitrate and urea. These represent two common fertigation programs used in the region. Total fertilizer $\mathrm{N}$ rates were $15,17.5$, and $20 \mathrm{lb} /$ acre per week $\mathrm{N}$ delivered in two equal applications per week. Total season $\mathrm{N}$ rates were 175,200 , and $225 \mathrm{lb} /$ acre $\mathrm{N}$ for both fertilizer programs. Because each liquid fertilizer program contained $\mathrm{K}$, season total $\mathrm{K}$ applications increased with increasing $\mathrm{N}$ fertilizer rates. There were minor differences in $\mathrm{K}$ applications between the two liquid fertilizer programs. In the supplemental $\mathrm{Ca}$ (4-0-8/CN9) program, 175, 200, and $225 \mathrm{lb} /$ acre $\mathrm{N}$ treatments received 124, 145, and $165 \mathrm{lb} /$ acre $\mathrm{K}$, respectively, through fertigation. In the program without $\mathrm{Ca}(7-0-7)$, 175,200 , and $225-\mathrm{lb} /$ acre $\mathrm{N}$ treatments received 121,141 , and $160 \mathrm{lb} /$ acre $\mathrm{K}$, respectively, via fertigation. In plots receiving additional $\mathrm{Ca} \approx 92$, 107 , and $122 \mathrm{lb} /$ acre Ca were applied to the treatments receiving 175,200 , $225 \mathrm{lb} /$ acre N, respectively.

Liquid fertilizers were analyzed for levels of nitrate, ammonium, and urea (Waters Agricultural Laboratories). The $4-0-8$ liquid fertilizer contained $2.4 \%$ nitrate $-\mathrm{N}, 0.5 \%$ ammonium- $\mathrm{N}$, and $1.0 \%$ urea $-\mathrm{N}(3.9 \% \mathrm{~N})$. The $7-0-7$ fertilizer contained $5.1 \%$ nitrate- $\mathrm{N}, 1.7 \%$ ammonium-N, and $0 \%$ urea- $-\mathrm{N}(6.8 \%$ $\mathrm{N})$. The CN9 fertilizer contained $7.4 \%$ nitrate- $\mathrm{N}, 0.8 \%$ ammonium $\mathrm{N}$, and $0.6 \%$ urea $-\mathrm{N}(8.8 \% \mathrm{~N})$. Those plants grown using the 7-0-7 fertilizer received $\approx 75 \%$ nitrate $-\mathrm{N}$, whereas those grown using the 4-0$8 / \mathrm{CN} 9$ program received $\approx 73 \% \mathrm{ni}^{-}$ trate-N. Fertilizer treatments started $\approx 10 \mathrm{~d}$ after transplant and were conducted for 10 weeks during growth. Different fertilizer programs were applied to plots using an electric pump and injection manifold, which supplied each plot with the appropriate amount of premeasured fertilizer. Before injections, irrigation lines were filled completely with water.
After injecting fertilizer, the irrigation systems were flushed for $\approx 20$ min to ensure fertilizer had been removed from the lines. Irrigation was applied daily to all plots equally during the growing season with the volume based on a growth-stage dependent evapotranspiration model for Northwest Florida (Dukes et al., 2015). Daily average irrigation run times ranged from $\approx 45$ min early in the season to nearly than $2.5 \mathrm{~h}$ during times of peak evapotranspiration. Late season applications were split into two irrigations per day. Although soil moisture levels were not monitored, symptoms of water stress were not observed in plants during the study.

In both years, bell pepper plants were staked and strung about 3 weeks after planting using standard practices for the region. Fungicides and insecticides were applied weekly according to commercial recommendations for bell pepper grown in Georgia (Horton, 2016). Bell pepper foliar nutrient concentrations were determined during fruiting (8 weeks posttransplant) by taking one newest fully expanded leaf from 20 representative plants in each plot. Leaves were briefly rinsed with distilled water and each sample was over dried at $65^{\circ} \mathrm{C}$ to a constant weight. Samples were analyzed by a commercial laboratory (Waters Agricultural Laboratory) for nutrient content.

Bell pepper fruit were harvested at a mature green stage on 27 June and 4 July 2016 and 25 May, 5 and 22 June 2017. All fruit were counted, weighed, and graded according to U.S. Department of Agriculture grade standards for grades of sweet peppers (U.S. Department of Agriculture, 2005) as well as industry specifications. Because U.S. Department of Agriculture grade standards are broader than industry standards regarding fruit size requirements, fruit were graded according industry size standards where jumbo fruit were greater than 3.75 inches in diameter, extra-large were 3.51 to 3.75 inches in diameter, large were 3.26 to 3.50 inches in diameter, and medium were 3.0 to 3.25 inches in diameter. Chopper fruit are those that were misshapen but otherwise had no visible defects and could be sold for processing. Cull fruit were divided into those with BER or sunburn and other defects. Weights of fruit were converted to a 28 -lb box and analyzed on a box per acre basis.

Weather data were monitored by an on-farm weather station from the University of Georgia Weather Network [Tifton Station, Tifton, GA (University of Georgia, 2018)]. Maximum, minimum, and average air temperatures, relative humidity, and rainfall were recorded hourly and daily averages calculated.

Data were analyzed using the linear mixed model as implemented in SAS PROC MIXED (version 9.3; SAS Institute, Cary, NC). Data were analyzed for the presence of significant main effects and interactions. When interactions among factors were present main effects for those factors were not considered for further analysis. Least-square means comparisons were performed using the Fisher's least significant difference test $(P<0.05)$.

\section{Results and discussion}

In general, the growing season in 2016 was warmer and drier than in 2017 (Table 1). There were $26 \mathrm{~d}$ when high temperatures exceeded 90 ${ }^{\circ} \mathrm{F}$ in 2016 compared with $8 \mathrm{~d}$ in 2017 , which resulted in a greater average maximum air temperature in 2016 than in 2017. Cumulative rainfall was also nearly 2 inches lower in 2016 than 2017. Average relative humidity during the study was $71.1 \%$ and $72.1 \%$ in 2016 and 2017 , respectively. During the last $40 \mathrm{~d}$ of the growing season, when bell pepper fruit set and maturation occurred, the relative humidity differences were more notable. Average daily relative humidity values during this time period were $73.2 \%$ and $80.0 \%$ in 2016 and 2017, respectively (Table 1 ). Increases in relative humidity often have been associated with decreased accumulation of $\mathrm{Ca}$ in pepper and tomato fruit (Banuelos and Offermann, 1985; Tadesse et al., 2001). Calcium accumulation in fruit has been positively associated transpiration rate (Taylor and Locascio, 2004), which is often negatively affected by increased relative humidity. Main effects of study year on BER are not presented due to interactions between year, fertilizer source, and rate (Table 2). However, rates of BER in pepper fruit were lower in in most treatments in 2017 compared with 2016 (Table 2), suggesting that the 
increased relative humidity during fruit set and maturation in 2017 may not have affected BER incidence. Marcelis and Ho (1999) reported a positive correlation between growth rate and BER incidence in pepper. In the present study, the increased average temperatures observed in 2016 may have contributed to a greater growth rate and incidence of BER compared with 2017.

There was a significant interaction between study year, fertilizer rate, and the presence of $\mathrm{Ca}$ in the fertilizer program for all yield parameters. There were year-by-variety interactions for several yield parameters as well (Table 2). In 2016, plants grown with supplemental $\mathrm{Ca}(4-0-8 / \mathrm{CN} 9$ program) at $175 \mathrm{lb} /$ acre $\mathrm{N}$ had significantly greater total yields [910 boxes/ acre $(28 \mathrm{lb} /$ box $)]$ than those grown without additional $\mathrm{Ca}$ at the same $\mathrm{N}$ rate (590 boxes/acre). Total yields for plants grown at 200 and $225 \mathrm{lb} /$ acre $\mathrm{N}$ were not significantly different between the two fertilizer programs in 2016. Commercial growers in the region expect to average 1000 boxes/ acre (Fonsah, 2009). While the greatest yielding treatments in 2016 were $9 \%$ to $13 \%$ lower than average commercial yields for the region, the lowest yielding treatments would be considered below expected yields for growers. Trends for yield of jumbo fruit, the majority of graded fruit in this study, were proportional to total yields (Table

Table 1 . Accumulated rainfall and the average daily maximum $\left(\mathrm{T}_{\max }\right)$ and minimum $\left(T_{\min }\right)$ temperatures and relative humidity at the trial location for bell pepper grown in Tifton, GA, in 2016 and 2017.

\begin{tabular}{lccccc}
\hline & \multicolumn{2}{c}{ Temp $\left({ }^{\circ} \mathbf{F}\right)^{\mathrm{z}}$} & & \multicolumn{2}{c}{ Relative humidity (\%) } \\
\cline { 2 - 5 } \cline { 5 - 6 } & $\mathrm{T}_{\max }$ & $\mathrm{T}_{\min }$ & Rainfall (inches) & Season long & Fruit development \\
\hline 2016 & 84.4 & 63.3 & 8.37 & 71.1 & 73.2 \\
2017 & 82.7 & 60.7 & 10.30 & 72.1 & 80.0
\end{tabular}

${ }^{\mathrm{z}}\left({ }^{\circ} \mathrm{F}-32\right) \div 1.8={ }^{\circ} \mathrm{C}, \mathrm{l}$ inch $=2.54 \mathrm{~cm}$.

Table 2. Interactions for marketable yields of total, jumbo, extra-large, large, and medium fruit as well as culls due to blossom end rot (BER) and other causes for two varieties of bell pepper grown with two liquid fertilizers (with or without calcium) and three nitrogen (N) levels in Tifton, GA, in 2016 and 2017.

\begin{tabular}{|c|c|c|c|c|c|c|c|c|c|}
\hline \multirow{2}{*}{$\begin{array}{l}\text { Fertilizer } \\
\text { program }^{z}\end{array}$} & \multirow[b]{2}{*}{$\mathbf{N}(\mathrm{lb} / \mathrm{acre})^{\mathrm{y}}$} & \multicolumn{6}{|c|}{ Marketable yield (boxes/acre) ${ }^{\mathrm{x}}$} & \multicolumn{2}{|c|}{ Culls (\%) ${ }^{\mathrm{w}}$} \\
\hline & & Total & Jumbo & Extra-large & Large & Medium & Chopper & BER & Other \\
\hline & & \multicolumn{8}{|c|}{2016} \\
\hline \multirow[t]{3}{*}{$4-0-8 / \mathrm{CN} 9$} & 175 & $910 \mathrm{a}^{\mathrm{v}}$ & $530 \mathrm{ab}$ & $270 \mathrm{a}$ & $80 \mathrm{c}$ & $20 \mathrm{de}$ & $120 \mathrm{bc}$ & $14.4 \mathrm{cde}$ & $3.1 \mathrm{f}$ \\
\hline & 200 & $880 \mathrm{ab}$ & $540 \mathrm{ab}$ & $240 \mathrm{ab}$ & $90 \mathrm{c}$ & $10 \mathrm{e}$ & $120 \mathrm{bc}$ & $16.5 \mathrm{~cd}$ & $4.5 \mathrm{f}$ \\
\hline & 225 & $870 \mathrm{ab}$ & $560 \mathrm{a}$ & $210 \mathrm{abc}$ & $80 \mathrm{c}$ & $20 \mathrm{de}$ & $80 \mathrm{c}$ & $20.2 \mathrm{bc}$ & $4.3 \mathrm{f}$ \\
\hline \multirow[t]{4}{*}{$7-0-7$} & 175 & 590 ef & $280 \mathrm{~cd}$ & $200 \mathrm{abc}$ & $80 \mathrm{c}$ & $20 \mathrm{de}$ & $70 \mathrm{c}$ & $26.7 \mathrm{a}$ & $9.0 \mathrm{de}$ \\
\hline & 200 & $740 \mathrm{a}-\mathrm{e}$ & $400 \mathrm{abc}$ & $210 \mathrm{abc}$ & $80 \mathrm{c}$ & $30 \mathrm{cde}$ & $80 \mathrm{c}$ & $27.2 \mathrm{a}$ & $6.7 \mathrm{ef}$ \\
\hline & 225 & $690 \mathrm{~b}-\mathrm{e}$ & $360 \mathrm{bcd}$ & $230 \mathrm{ab}$ & $90 \mathrm{c}$ & 10 cde & $80 \mathrm{c}$ & $22.9 \mathrm{ab}$ & $5.9 \mathrm{ef}$ \\
\hline & & \multicolumn{8}{|c|}{2017} \\
\hline \multirow[t]{3}{*}{$4-0-8 / \mathrm{CN} 9$} & 175 & $790 \mathrm{a}-\mathrm{d}$ & $310 \mathrm{~cd}$ & $220 \mathrm{abc}$ & $170 \mathrm{a}$ & $90 \mathrm{ab}$ & $230 \mathrm{a}$ & $12.8 \mathrm{de}$ & $14.7 \mathrm{bc}$ \\
\hline & 200 & $530 \mathrm{f}$ & $190 \mathrm{~d}$ & $160 c$ & $130 \mathrm{abc}$ & $60 \mathrm{abc}$ & $180 \mathrm{ab}$ & $13.4 \mathrm{de}$ & $19.9 \mathrm{a}$ \\
\hline & 225 & 750 a-e & $320 \mathrm{~cd}$ & $210 \mathrm{abc}$ & $140 \mathrm{ab}$ & $90 \mathrm{ab}$ & $240 \mathrm{a}$ & $8.5 \mathrm{e}$ & $11.2 \mathrm{~d}$ \\
\hline \multirow[t]{3}{*}{$7-0-7$} & 175 & 650 def & $230 \mathrm{~cd}$ & $180 \mathrm{bc}$ & $150 \mathrm{ab}$ & $90 \mathrm{a}$ & $200 \mathrm{a}$ & $10.6 \mathrm{de}$ & $11.1 \mathrm{~cd}$ \\
\hline & 200 & 690 def & $350 \mathrm{bcd}$ & $190 \mathrm{bc}$ & $100 \mathrm{bc}$ & $50 \mathrm{bcd}$ & $180 \mathrm{ab}$ & $13.5 \mathrm{de}$ & $16.0 \mathrm{ab}$ \\
\hline & 225 & $750 \mathrm{a}-\mathrm{e}$ & $330 \mathrm{~cd}$ & $200 \mathrm{bc}$ & $130 \mathrm{ab}$ & $80 \mathrm{ab}$ & $190 \mathrm{a}$ & $11.0 \mathrm{de}$ & $16.3 \mathrm{ab}$ \\
\hline Variety & & \multicolumn{8}{|c|}{2016} \\
\hline PSO9979325 & & $790 \mathrm{a}$ & $480 \mathrm{a}$ & $240 \mathrm{a}$ & $60 c$ & $10 \mathrm{c}$ & $70 \mathrm{~d}$ & $23.4 \mathrm{~b}$ & $5.5 \mathrm{c}$ \\
\hline Antebellum & & $750 \mathrm{ab}$ & $410 \mathrm{a}$ & $220 \mathrm{a}$ & $100 \mathrm{~b}$ & $30 \mathrm{bc}$ & $110 \mathrm{c}$ & $20.0 \mathrm{a}$ & $5.7 \mathrm{c}$ \\
\hline & & \multicolumn{8}{|c|}{2017} \\
\hline PSO9979325 & & $720 \mathrm{ab}$ & $360 \mathrm{a}$ & $190 \mathrm{~b}$ & $120 \mathrm{~b}$ & $50 \mathrm{~b}$ & $160 \mathrm{~b}$ & $13.4 \mathrm{c}$ & $16.5 \mathrm{a}$ \\
\hline Antebellum & & $660 \mathrm{~b}$ & $210 \mathrm{~b}$ & $200 \mathrm{ab}$ & $150 \mathrm{a}$ & $90 \mathrm{a}$ & $240 \mathrm{a}$ & $10.0 \mathrm{c}$ & $13.4 \mathrm{~b}$ \\
\hline
\end{tabular}

${ }^{\mathrm{z}} 7-0-7=7 \mathrm{~N}-0 \mathrm{P}-5.8 \mathrm{~K}, 4-0-8=4 \mathrm{~N}-0 \mathrm{P}-6.6 \mathrm{~K}, \mathrm{CN} 9=9 \mathrm{~N}-0 \mathrm{P}-0 \mathrm{~K}-1 \mathrm{lCa}$.

${ }^{\mathrm{y}} \mathrm{llb} /$ acre $=1.1209 \mathrm{~kg} \cdot \mathrm{ha}^{-1}$.

${ }^{\mathrm{x}} \mathrm{Jumbo}>3.75$ inches, extra-large $=3.51-3.75$ inches, large $=3.26-3.50$ inches, medium $=3.00-3.25$ inches, chopper $=$ fruit that are misshapen but otherwise without defects or damage; 1 inch $=2.54 \mathrm{~cm}, 128-\mathrm{lb}(12.7 \mathrm{~kg})$ box $/$ acre $=24.6587 \mathrm{~kg} \cdot \mathrm{ha}^{-1}$.

${ }^{\mathrm{w}}$ Cull percentage is based on the number of nonmarketable fruit divided by the total number of fruit harvested. Other reasons for cull fruit were primarily due to sunscald but also included cracking, insect, and disease damage.

"Values in the same column and treatment group followed by the same letter(s) are not significantly different at $P \leq 0.05$ according to Fisher's least significant difference test. 
greater in 2017 than in 2016, which may have resulted in lower marketable yields.

In 2017, yields of large fruit, which ranged from 100 to 170 boxes/acre, were greater than in 2016 for all but one treatment combination. Similarly, medium fruit, which made up the smallest portion of fruit harvested, had significantly greater yields in 2017 compared with 2016 in four of the six fertilizer treatments. This suggests that fruit size decreased in 2017 compared with 2016. Fruit graded into the chopper category were those that were misshapen, but otherwise defect free. These fruit can be sold by growers for processing at a reduced rate. Yield of chopper fruit was unaffected by treatment in during a single growing season, but several treatments differed between growing seasons. Yields of chopper fruit ranged from 70 to 240 boxes/acre across both study years and were significantly greater in several treatments in 2017 compared with 2016 . Yields of chopper fruit were between $11 \%$ to $31 \%$ of marketable yields for both study years. This was comparable with levels observed in variety trials conducted during the same time period at the same farm (Coolong, 2017).

Percentages of cull fruit caused by BER and other factors also were affected by a significant year by fertilizer source by fertilizer rate interaction (Table 2). Most of the fruit affected by BER were those that were set earliest in the season and were present in the first harvest. The percentages of cull fruit due to BER were not different among fertilizer treatments in 2017 but were affected by $\mathrm{Ca}$ treatment and $\mathrm{N}$ fertilizer rates in 2016. In 2016, the percentages of cull fruit due to BER were lowest in plants grown with supplemental $\mathrm{Ca}$ at $175 \mathrm{lb} /$ acre N (14.4\%) and greatest in plants grown without additional $\mathrm{Ca}$ at $175 \mathrm{lb} /$ acre $\mathrm{N}(26.7 \%)$. Although the total amount of $\mathrm{Ca}$ applied with fertigation was a relatively small portion of the total available Ca measured in soil tests, the weekly application of additional amounts of soluble Ca may have resulted in lower BER incidence in 2016. The treatments with the greatest levels of BER were plants grown without supplemental $\mathrm{Ca}$ at 175 and $200 \mathrm{lb} /$ acre $\mathrm{N}$ in 2016. Within a fertilizer program, there was no effect of $\mathrm{N}$ rate on BER levels in fruit. Because both fertilizer programs also applied $\mathrm{K}$ with $\mathrm{N}$, increased $\mathrm{N}$ applications also would have resulted in increased K applied. Studies have shown that increasing $\mathrm{K}$ application rates may reduce $\mathrm{Ca}$ accumulation in plants (Mardanluo et al., 2018) and increase rates of BER (Bar-Tal and Pressman, 1996). The reduction in Ca uptake is the result of cation competition, much in the way that ammonium reduces Ca uptake (Marti and Mills, 1991; Taylor and Locascio, 2004). However, at the levels evaluated in this study, increased $\mathrm{K}$ applications did not significantly affect BER. In addition, the percentage of nitrate$\mathrm{N}$ of total $\mathrm{N}$ in the two fertilizers were similar and ranged from $73 \%$ to $75 \%$. Therefore, although ammonium has been shown to affect BER, given the relatively low percentage of ammonium compared with nitrate in the fertilizers used in this trial it is unlikely that it affected BER rates. Due to the wide range of factors reported to impact BER incidence in bell pepper and tomato, variability within treatments and among years may be expected (Diaz-Perez and Hook, 2017; Taylor and Locascio, 2004).

Sunscald was responsible for the majority of cull fruit unaffected by BER. Sunscald incidence was lowest in five of the six fertilizer treatment combinations in 2016. In general sunscald incidence was lower in 2016 than 2017. However, there were no clear trends for the impact of fertilizer treatment on sunscald incidence. One may expect that high $\mathrm{N}$ treatments would have less sunscald due to an expected increase in plant canopy, but there were no significant differences between $\mathrm{N}$ fertilizer rates observed in this study (Madramootoo and Rigby, 1991).

Although variety did not interact with fertilizer treatments, there were several significant interactions between variety and study year affecting yields (Table 2 ). Total yield and jumbo fruit yield were lower in 'Antebellum' compared with 'PSO9979325' in 2017 but were not different between the two varieties in 2016. There were significantly more medium and large fruit produced by 'Antebellum' compared with 'PS09979325' in 2017. This may be expected, as 'PS09979325' generally has been reported to be larger and have a blockier fruit shape than
'Antebellum' (Coolong, 2017). Cull fruit due to BER were lower in 'Antebellum' in 2016 compared with 'PSO9979325', although the two were not significantly different in 2017. The larger 'PS09979325' fruit may have had an increased growth rate, resulting in potential for increased BER incidence compared with the smaller 'Antebellum' fruit (Marcelis and Ho, 1999). Rates of sunscald were highest in 'PSO9979325' in 2017 and both varieties had greater rates of sunscald in 2017 compared with 2016.

There were no significant interactions between the treatment variables for foliar macronutrient concentrations. Nitrogen fertilizer rate and year significantly affected foliar $\mathrm{N}$ and $\mathrm{K}$ concentrations, whereas variety and supplemental Ca fertilizer did not. Therefore, only data for the main effects of fertilizer rate and year are presented (Table 3). Foliar $\mathrm{N}$ concentrations significantly increased in plants grown in the $200-\mathrm{lb} /$ acre $\mathrm{N}$ (4.65\%) and 225-lb/acre N (4.69\%) treatments compared with those in the $175-\mathrm{lb} /$ acre $\mathrm{N}(4.32 \%)$ treatment. In addition, there was a trend for foliar $\mathrm{K}$ concentrations to increase with $\mathrm{N}$ fertilizer rate. Foliar $\mathrm{K}$ concentrations were significantly greater in plants receiving $225 \mathrm{lb} /$ acre $\mathrm{N}$ (5.67\%) compared with those in the 175- and 225-lb/acre $\mathrm{N}$ treatments, which had foliar $\mathrm{K}$ concentrations of $5.49 \%$ and $5.52 \%$, respectively. This may be expected as the fertilizers applied contained $\mathrm{N}$ and $\mathrm{K}$, and increases in fertilizer application rates would have resulted in additional $\mathrm{N}$ and K being supplied to plants. This indicates that although there may not have been observed differences in plant growth between fertilizer rates, the treatments were effectively delivered to the plants. No other foliar nutrients were affected by fertilizer rate, and concentrations were within normal ranges for all nutrients (Bryson et al., 2014). Despite some differences in BER incidence among the two fertilizer programs in 2016 , foliar Ca levels were unaffected by either treatment. In tomato, foliar and fruit $\mathrm{Ca}$ concentrations have been shown to be poorly correlated (Coolong et al., 2014) and foliar Ca values may not be a good predictor for BER. Foliar concentrations averaged $0.23 \%$ for $\mathrm{P}, 0.38 \%$ for magnesium $(\mathrm{Mg})$ and $0.44 \%$ for sulfur and were unaffected by fertilizer rate. The foliar concentrations of micronutrients were unaffected by fertilizer rate. Average concentrations among the three 
Table 3. Foliar concentrations of nitrogen $(\mathrm{N})$, phosphorous $(\mathrm{P})$, potassium $(\mathrm{K})$, calcium $(\mathrm{Ca})$, magnesium $(\mathrm{Mg})$, sulfur $(\mathrm{S})$, boron $(\mathrm{B})$, iron $(\mathrm{Fe})$, zinc $(\mathrm{Zn})$, manganese $(\mathrm{Mn})$, and copper $(\mathrm{Cu})$ for bell pepper grown at three rates of $\mathrm{N}$ fertility in Tifton, GA, in Spring 2016 and 2017. Plants were sampled during fruit maturation.

\begin{tabular}{|c|c|c|c|c|c|c|c|c|c|c|c|c|c|c|c|c|c|c|c|c|c|}
\hline \multirow{2}{*}{$\begin{array}{l}\text { Fertilizer rate } \\
(\text { lb/acre } N)^{z}\end{array}$} & \multicolumn{12}{|c|}{ Foliar concn ( $\%$ dry wt) } & \multicolumn{9}{|c|}{ Foliar concn (ppm dry wt $)^{\mathrm{z}}$} \\
\hline & $\mathbf{N}$ & & $\mathbf{P}$ & & $\mathbf{K}$ & & $\mathbf{C a}$ & & Mg & & $S$ & & B & & $\mathrm{Fe}$ & & $\mathbf{Z n}$ & & Mn & & $\mathbf{C u}$ \\
\hline 175 & 4.32 & $b^{y}$ & 0.23 & & 5.49 & $\mathrm{~b}$ & 1.59 & & 0.36 & & 0.46 & & 59 & & 99 & & 88 & & 152 & & 163 \\
\hline 225 & 4.69 & $\mathrm{a}$ & 0.23 & & 5.67 & $\mathrm{a}$ & 1.67 & & 0.40 & & 0.43 & & 60 & & 99 & & 87 & & 151 & & 143 \\
\hline \multicolumn{22}{|l|}{ Year } \\
\hline 2016 & 4.99 & $\mathrm{a}$ & 0.28 & $\mathrm{a}$ & 5.74 & $\mathrm{a}$ & 1.23 & $\mathrm{~b}$ & 0.31 & $\mathrm{~b}$ & 0.51 & $\mathrm{a}$ & 70 & $\mathrm{a}$ & 114 & $\mathrm{a}$ & 112 & $\mathrm{a}$ & 148 & $\mathrm{a}$ & 227 \\
\hline
\end{tabular}

${ }^{\mathrm{z}} \mathrm{l} \mathrm{lb} /$ acre $=1.1209 \mathrm{~kg} \cdot \mathrm{ha}^{-1}, \mathrm{l} \mathrm{ppm}=1 \mathrm{mg} \cdot \mathrm{kg}^{-1}$

${ }^{y}$ Values within the same column and treatment group followed by the same letter(s) are not significantly different at $P \leq 0.05$ according to Fisher's least significant difference test.

fertilizer rates were $59 \mathrm{ppm}$ for boron (B), 100 ppm for iron (Fe), 88 ppm for zinc $(\mathrm{Zn})$, and $151 \mathrm{ppm}$ for manganese $(\mathrm{Mn})$, which are typical ranges reported for bell pepper at the fruiting growth stage (Bryson et al., 2014). Average foliar copper $(\mathrm{Cu})$ concentrations were 144 ppm among the three fertilizer rates, but this concentration was affected significantly by trial year (Table 3 ).

With the exception of Mn, study year significantly affected all foliar nutrient concentrations. Foliar N, P, $\mathrm{K}$, and sulfur all decreased significantly in 2017 compared with 2016. Foliar N concentrations decreased from $4.99 \%$ in 2016 to $4.01 \%$ in 2017. Similarly, foliar P and K concentrations decreased from $0.28 \%$ to $0.17 \%$ and $5.74 \%$ to $5.33 \%$ in 2016 and 2017, respectively. Interestingly, foliar $\mathrm{Ca}$ and $\mathrm{Mg}$ concentrations increased in 2017 compared with 2016. The change in foliar $\mathrm{Ca}$ was most notable, increasing from $1.23 \%$ in 2016 to $2.15 \%$ in 2017. Although there was an interaction present, BER rates were lower in most treatments in 2017 compared with 2016 (Table 2). Although foliar $\mathrm{Ca}$ has not been shown to be a good indicator of BER (Coolong et al., 2014), the relatively large $(74 \%)$ increase in foliar Ca in 2017 compared with 2016 may have been sufficient to influence BER rates. As with $\mathrm{Ca}$, and in contrast with other nutrients, foliar $\mathrm{Mg}$ levels increased in 2017 compared with 2016. Foliar micronutrient concentrations were also impacted by study year. There was a significant year-by-variety interaction for foliar $\mathrm{B}$ and $\mathrm{Mn}$ levels (Table 4). Foliar B, Fe, Zn, and Cu were affected by study year as well. With the exception of $\mathrm{Mn}$, foliar micronutrient concentrations decreased significantly in

Table 4. Interactions for foliar concentrations boron $(\mathrm{B})$, iron $(\mathrm{Fe})$, zinc $(\mathrm{Zn})$, manganese $(\mathrm{Mn})$, and copper $(\mathrm{Cu})$ for two varieties of bell pepper grown in Tifton, GA, in Spring 2016 and 2017. Plants were sampled during fruit maturation.

\begin{tabular}{|c|c|c|c|c|c|c|c|c|c|c|c|}
\hline \multirow{3}{*}{$\frac{\text { Yr }}{2016}$} & \multirow{3}{*}{$\frac{\text { Variety }}{\text { SO9979325 }}$} & \multicolumn{10}{|c|}{ Foliar concn (ppm dry wt $)^{\mathrm{z}}$} \\
\hline & & \multicolumn{2}{|c|}{ B } & \multicolumn{2}{|c|}{$\mathrm{Fe}$} & \multicolumn{2}{|c|}{$\mathbf{Z n}$} & \multicolumn{2}{|c|}{ Mn } & \multicolumn{2}{|c|}{$\mathbf{C u}$} \\
\hline & & 60 & $b^{y}$ & 117 & $\mathrm{a}$ & 119 & $\mathrm{a}$ & 139 & $\mathrm{~b}$ & 238 & $\mathrm{~d}$ \\
\hline & Antebellum & 78 & $\mathrm{a}$ & 112 & $\mathrm{a}$ & 107 & $\mathrm{a}$ & 154 & $\mathrm{ab}$ & 219 & $\mathrm{a}$ \\
\hline \multirow[t]{2}{*}{2017} & PSO9979325 & 45 & $\mathrm{c}$ & 83 & $\mathrm{~b}$ & 59 & $\mathrm{~b}$ & 151 & $\mathrm{ab}$ & 42 & $\mathrm{~b}$ \\
\hline & Antebellum & 46 & $\mathrm{c}$ & 80 & $\mathrm{~b}$ & 56 & $\mathrm{~b}$ & 158 & a & 45 & $\mathrm{~b}$ \\
\hline
\end{tabular}

${ }^{\mathrm{z}} \mathrm{l} \mathrm{ppm}=1 \mathrm{mg} \cdot \mathrm{kg}^{-1}$

yalues within the same column followed by the same letter(s) are not significantly different at $P \leq 0.05$ according to Fisher's least significant difference test.

2017 compared with 2016. Foliar B, Fe, and $\mathrm{Zn}$ concentrations decreased by $37 \%, 28 \%$, and $48 \%$, respectively in 2017 compared with 2016. Nonetheless, foliar micronutrient concentrations were within acceptable ranges for bell pepper in both study years (Bryson et al., 2014). Copper concentrations (227 ppm) were greater than typical levels in 2016 but were within typical ranges (43 ppm) in 2017. An explanation for such high Cu levels in 2016 may be that residual $\mathrm{Cu}$ from weekly spray applications of $\mathrm{Cu}$-based bactericides may have been present on leaf surfaces or had been absorbed by leaves at greater than typical concentrations. Throughout the study no plants exhibited any visual nutrient deficiency or toxicity symptoms. The growing season in 2017 was cooler than 2016 on average, which may have contributed to the lower concentration levels of most foliar macronutrients in 2017 (Marschner, 1995). However, Ca and $\mathrm{Mg}$ concentrations increased in 2017, suggesting they may have responded differently to growing conditions than the others. Calcium uptake, in particular, has been shown to be affected by a range of environmental variables (Taylor and Locascio, 2004).
There were significant year-byvariety interactions for foliar concentrations of $\mathrm{B}$ and $\mathrm{Mn}$ (Table 4). In 2016 foliar B concentrations were significantly greater in 'Antebellum' compared with 'PSO9979325', whereas in 2017 there were no differences between the two varieties. Foliar B concentrations were also significantly lower in both varieties in 2017 compared with 2016. Foliar Mn concentrations were more variable, with 'PSO997932' in 2016, having significantly lower foliar $\mathrm{Mn}$ concentrations than 'Antebellum' in 2017.

\section{Conclusions}

There have been several studies evaluating total $\mathrm{N}$ requirements for bell pepper as well as factors that may affect BER. However, it has been nearly 40 years since field-based $\mathrm{N}$ trials have been conducted in Georgia, which is a major bell pepperproducing state (Batal and Smittle, 1981). The present study sought to evaluate $\mathrm{N}$ fertilizer rate recommendations with varieties and fertilizer sources used widely by growers in Georgia and Florida. Although an increase in yield was not observed 
with increasing fertilizer rates, total yields were lower than what is commercially expected for the region. Additional research may be required at greater $\mathrm{N}$ rates to determine whether current recommendations for $\mathrm{N}$ fertility are appropriate. Other factors in addition to total season $\mathrm{N}$ applications, such as frequency of fertigation and preplant $\mathrm{N}$ fertilizer levels, also may have an impact on yield. Although not all treatments were significantly different between the two fertilizer programs, in 2016 treatments receiving supplemental $\mathrm{Ca}$ (4-0-8/ CN9) had a lower incidence of BER for two of the three $\mathrm{N}$ rates compared with the 7-0-7 fertilizer program. Because $\mathrm{K}$ levels were about balanced between the two fertilizer programs, this suggests that the presence of additional $\mathrm{Ca}$ in the 4-0-8/CN9 fertilizer program may have been beneficial. The decrease in BER in 2017 also demonstrated the large impact that growing season can have on BER. Nonetheless, our data suggest that supplemental Ca delivered throughout the growing season may have a positive impact on BER, although this may vary from season to season, as other factors may have more pronounced effects on BER than the presence of supplemental $\mathrm{Ca}$ in a fertilizer program.

\section{Literature cited}

Aliyu, L. 2000. Effect of organic and mineral fertilizers on growth, yield and composition of pepper (Capsicum annunm L.). Biol. Agr. Hort. 18:29-36.

Bangerth, F. 1979. Calcium-related physiological disorders of plants. Annu. Rev. Phytopathol. 17:97-122.

Banuelos, G.S. and G.P. Offermann. 1985. High relative-humidity promotes blossom-end rot on growing tomato fruit. HortScience 20:894-895.

Bar-Tal, A. and E. Pressman. 1996. Root restriction and potassium and calcium solution concentrations affect dry matter production, cation uptake, and blossomend rot in greenhouse tomato. J. Amer. Soc. Hort. Sci. 121:649-655.

Batal, K.M. and D.A. Smittle. 1981. Response of bell pepper to irrigation, nitrogen, and plant population. J. Amer. Soc. Hort. Sci. 106:259-262.

Bryson, G.M., H.A. Mills, D.N. Sasseville, J.B. Jones, and A.V. Barker. 2014. Plant analysis handbook III. Micro Macro Publ., Athens, GA.
Coolong, T., S. Mishra, C. Barickman, and C. Sams. 2014. Impact of supplemental calcium chloride on yield, quality, nutrient status, and postharvest attributes of tomato. J. Plant Nutr. 37:2316-2330.

Coolong, T. 2017. Trial report: Bell pepper variety evaluation Spring 2017. 4 Nov. 2018. <http://vegetables.caes.uga. edu/content/dam/caes-website/ extension-outreach/commodities / vegetables/docs/trial-results/2017-\% 20Spring-Bell-Pepper-Trial.pdf $>$.

Delgado, J.A. 2002. Quantifying the loss mechanisms of nitrogen. J. Soil Water Conserv. 57:389-398.

Diaz-Perez, J.C. and J.E. Hook. 2017. Plastic-mulched bell pepper (Capsicum annuиm L.) plant growth and fruit yield and quality as influenced by irrigation rate and calcium fertilization. HortScience 52:774-781.

Dukes, M.D., L. Zotarelli, G.D. Liu, and E.H. Simonne. 2015. Principles and practices of irrigation management for vegetables. Univ. Florida Inst. Food Agr. Sci. Bul. AE260.

Fonsah, E.G. 2009. Production costs, p. 51-55. In: T. Kelley and G. Boyhan (eds.). Commercial pepper production handbook. Univ. Georgia Coop Ext. Serv. Bul. 1309.

Granberry, D.M., K.A. Harrison, and W.T. Kelley. 2017. Drip chemigation: Injection fertilizer, acid, and chlorine. Univ. Georgia Coop. Ext. Serv. Special Bul. 1130.

Hartz, T.K., M. LeStrange, and D.M. May. 1993. Nitrogen requirements of drip-irrigated peppers. HortScience 28: 1097-1099.

Hochmuth, G. and E. Hanlon. 2010. A summary of $\mathrm{N}, \mathrm{P}$, and $\mathrm{K}$ research with pepper in Florida. Univ. Florida Inst. Food Agr. Sci. Bul. SL334.

Horton, D. 2016. 2016 Georgia pest management handbook. Univ. Georgia Coop. Ext. Serv. Spec. Bul. 28.

Kissel, D.E. and L. Sonon. 2008. Soil test handbook for Georgia. Univ. Georgia Coop. Ext. Serv. Spec. Bul. 62.

Kline, W.L., C.A. Wyenandt, D.L. Ward, J.F. Sudal, and N.L. Maxwell. 2011. Evaluation of six nitrogen fertility programs on marketable yield and development of skin separation in bell pepper fruit. HortTechnology 21:323-328.

Madramootoo, C.A. and M. Rigby. 1991. Effects of trickle irrigation on the growth and sunscald of bell peppers (Capsicum anum L.) in southern Quebec. Agr. Water Mgt. 19:181-189.

Marcelis, L.F.M. and L.C. Ho. 1999. Blossom-end rot in relation to growth rate and calcium content in fruits of sweet pepper (Capsicum annuum L.). J. Expt. Bot. 50:357-363.

Mardanluo, S., M.K. Souri, and M. Ahmadi. 2018. Plant growth and fruit quality of two pepper cultivars under different levels of nutrient solutions. J. Plant Nutr. 41:1604-1614.

Marschner, H. 1995. Mineral nutrition of higher plants. 2nd ed. Academic Press, London, UK.

Marti, H.R. and H.A. Mills. 1991. Calcium uptake and concentration in bell pepper plants as influenced by nitrogen form and stages of development. J. Plant Nutr. 14:1177-1185.

Silber, A., M. Bruner, E. Kenig, G. Reshef, H. Zohar, I. Posalski, H. Yehezkel, D. Shmuel, S. Cohen, M. Dinar, E. Matan, I. Dinkin, Y. Cohen, L. Karni, B. Aloni, and S. Assouline. 2005. High fertigation frequency and phosphorous level: Effects on summer-grown bell pepper growth and blossom-end rot incidence. Plant Soil 270:135-146.

Simonne, E., M.D. Dukes, R.C. Hochmuth, D.W. Studstill, G. Avezou, and D. Jarry. 2006. Scheduling drip irrigation for bell pepper grown with plasticulture. J. Plant Nutr. 29:1729-1739.

Tadesse, T., M.A. Nichols, E.W. Hewett, and K.J. Fisher. 2001. Relative humidity around the fruit influences the mineral composition and incidence of blossomend rot in sweet pepper fruit. J. Hort. Sci. Biotechnol. 76:9-16.

Taylor, M.D. and S.J. Locascio. 2004. Blossom-end rot: A calcium deficiency. J. Plant Nutr. 27:123-139.

Taylor, M.D., S.J. Locascio, and M.R. Alligood. 2004. Blossom-end rot incidence of tomato as affected by irrigation quantity, calcium source, and reduced potassium. HortScience 39:1110-1115.

University of Georgia. 2018. Tifton, Georgia climate data. 10 Oct. 2018. $<$ http://www.georgiaweather.net/ index.php? content =calculator \& variable $=$ CC\&site $=$ TIFTON $>$.

U.S. Department of Agriculture. 2005. United States standards for grades of sweet peppers. U.S. Dept. Agr., Washington, DC.

Wolfe, K. and K. Stubbs. 2017. 2016 Georgia farm gate value report. Univ. Georgia Coop. Ext. Serv. Bul. AR-17-01.

Zhang, T.Q., K. Liu, C.S. Tan, J.P. Hong, and J. Warner. 2010. Evaluation of agronomic and economic effects of nitrogen and phosphorus additions to green pepper with drip fertigation. Agron. J. 102:1434-1440. 